\title{
Effects of dietary replacement of maize grain with popcorn waste products on nutrient digestibility and performance by lambs
}

\author{
B.D. Nkosi ${ }^{1 \#}$, R. Meeske ${ }^{2}$, H.J. van der Merwe ${ }^{3}$, O. Acheampong-Boateng ${ }^{4}$ and T. Langa ${ }^{1}$ \\ ${ }^{1}$ ARC-LBD: Animal Production Institute, P/Bag x2, Irene 0062, South Africa \\ ${ }^{2}$ Western Cape Department of Agriculture, P.O. Box 249, George 6530, South Africa \\ ${ }^{3}$ Department of Animal, Wildlife \& Grassland Science, University of the Free State, South Africa \\ ${ }^{4}$ Department of Animal Science, School of Agriculture, University of Venda, South Africa
}

\begin{abstract}
A study was conducted to evaluate the effects of dietary replacement of maize with popcorn waste (PW) on the intake, nutrient digestibility and growth performance of lambs. Diets replacing 0, 25, 50, 75 and $100 \%$ maize with PW were formulated and fed ad libitum to 40 South African Mutton Merino lambs (25.0 $\pm 0.45 \mathrm{~kg}$ live-weight). The diets had similar intake and nutrient digestibility of dry matter (DM), organic matter (OM) and neutral detergent fibre (NDF). Lambs fed the 25 and 50\% PW diets had higher intakes of crude protein (CP), metabolizable energy and ether extract compared to the other diets. Growth rate was highest $(226 \mathrm{~g} / \mathrm{d})$ on the $25 \%$ diet and lowest $(109 \mathrm{~g} / \mathrm{d})$ on the $75 \% \mathrm{PW}$ diet. Best feed conversion ratio (FCR), of 5.1 ( $\mathrm{kg}$ feed $/ \mathrm{kg}$ live weight) was obtained with the $0 \%$ PW diet. Improved digestibility of CP and EE occurred in the 25 and $75 \%$ PW diets. Higher intake of nitrogen $(\mathrm{N})$ and $\mathrm{N}$ retention were obtained in the 25 and $50 \%$ PW diets. Dietary replacement of $>75 \%$ of maize resulted in poor animal performance (ADG $<$ $150 \mathrm{~g} / \mathrm{d}$ and FCR $>7.00$ ). It was concluded that PW can replace up to $50 \%$ of the maize in diets for growing lambs.
\end{abstract}

Keywords: Average daily gain, by-products, lambs, maize, popcorn

${ }^{\#}$ Corresponding author. E-mail: dnkosi@arc.agric.za

\section{Introduction}

Popcorn, a popular snack (Schepers, 1989), is derived from the heating of dry maize grains in a hot-air popper at $180{ }^{\circ} \mathrm{C}$ and applying a pressure of about 135 psi to rupture the maize hull (Gokmen, 2004). In some cases, oil and salt are added to the maize grain during popping (Borras et al., 2006). During this process, some popcorn wastes (PW) become available and may be used as animal feed. There is more than $500 \mathrm{~kg}$ of PW per day available in the popcorn producing factories around the Johannesburg area of South Africa, which can be considered as replacement for maize grain in animal diets. It has been reported that popcorn contain nearly the same nutritional value as maize, with its energy content being $13.61 \mathrm{MJ}$ metabolizable energy (ME)/kg DM while that of maize is $14.34 \mathrm{MJ} \mathrm{ME} / \mathrm{kg} \mathrm{DM}$ (Anonymous, 1990). According to Ristanovic (2001), about $66 \%$ of the maize produced globally is used for animal nutrition and $25 \%$ for human consumption. In South Africa, almost $80 \%$ of the red meat produced is derived from feedlot operations where concentrate mixtures that contain $30-50 \%$ or even higher levels of maize are fed to animals (Strydom, 2008). With the increased demand for food by the increasing human population in this country, it is necessary to seek alternative energy sources for animal nutrition. Various efforts have been made to develop either low grain or diets with no grain by replacing maize grain with wheat bran (Dhakad et al., 2002), rice (Vicente et al., 2008) or barley grain (Lehmann \& Meeske, 2006) in animal diets. Only a few scientific studies have been undertaken to evaluate the feeding potential of popcorns or PW in livestock. For instance, animal production was not affected when maize was replaced with popcorn $(0,33$ and $67 \%)$ in a growing diet for pigs. It is important to establish the effects of dietary inclusion of PW on ruminants such as sheep, which play a vital role in the economy of South Africa. The aim of the study was to determine the effect of replacing maize grain with PW on the nutrient digestibility and growth performance of lambs. 


\section{Materials and Methods}

Popcorn wastes were collected from popcorn producing factories around the southern area of Johannesburg in South Africa. Five diets with different substitution levels of maize with PW $(0,25,50,75$ and $100 \%$ ) were formulated (Table 1) to provide in the minimum crude protein requirements of lambs (ARC, 1984). The diets were fed ad libitum to 40 South African Mutton Merino ram lambs $(18-24$ months old with a live weight of $25.0 \pm 0.45 \mathrm{~kg})$. The lambs were housed in individual metabolism crates $(1.2 \mathrm{~m}$ length x $0.74 \mathrm{~m}$ width x $0.92 \mathrm{~m}$ height) in an insulated well-ventilated barn. There were eight lambs per diet, randomly allocated. Water was freely available. Twenty one (21) days were allowed for adaptation, followed by a 60 days growth and data collection period. Feed samples were collected weekly and analysed for dry matter (DM), organic matter (OM), crude protein (CP), gross energy (GE), metabolizable energy (ME), ether extract (EE), neutral detergent fibre (NDF) and acid detergent fibre (ADF). Lambs were weighed at the start of the trial and thereafter at weekly intervals until the end of the trial. Feed samples were collected on a daily basis. Daily feed refusals per lamb were collected, weighed, thoroughly mixed and sub-sampled before the morning feeding. Feed intake, average daily gain (ADG) and feed conversion rate (FCR) were determined.

A nutrient digestibility study was conducted during the last 10 days of the growth study. It consisted of a three days adaptation period to faecal bags and a seven days collection period. Urine was collected in 10 litre buckets that contained $100 \mathrm{~mL}$ of $10 \%$ sulphuric acid. Samples of faeces and urine were pooled for individual lambs during the collection period and sub-samples were collected for laboratory analyses. All animals were treated according to the regulations of the Animal Ethics Committee of the ARC-API (2008).

The dry matter (DM) of diets and faeces was determined by drying the samples at $90{ }^{\circ} \mathrm{C}$ until a constant weight was achieved, following the procedure of AOAC (ID 934.01, 1990). After drying, the samples were ground through a 1-mm screen (Wiley mill, Standard Model 3, Arthur H. Thomas Co., Philadelphia, PA) for chemical analyses. Acid detergent fibre and NDF were determined according to Van Soest et al. (1991). Crude protein (ID 968.06), OM (ID 942.05) and EE (ID 963.15) were determined according to the procedure of AOAC (1990). The GE of diets, faeces and urine were determined with a bomb calorimeter (MC-1000 modular calorimeter, Energy Instrumentation, 135 Knoppieslaagte, Centurion, South Africa). The digestible energy (DE) values of the diets were determined by deducting energy in faeces from gross energy of the respective diets. The ME was determined by deducting energy of urine and energy loss as methane (assuming 6\% of GE is lost as methane) from the DE (Wedegaertner \& Johnson, 1983, McDonald et al., 1995). Analysis of $\mathrm{N}$ in the feeds, faeces and urine samples was done according to AOAC (ID 968.06, 1990).

Data of the means for the chemical composition, growth performance and nutrient digestibility in lambs were analysed in a completely randomized design for ANOVA using Genstat (2000). The differences among treatment means were compared with least significant difference (LSD) and significance was declared at 5\% probability level. The data was fitted with the Snedecor \& Cochran (1980) statistical model:

$$
Y_{i j}=\mu+t_{i}+\beta_{j}+\varepsilon_{i j}
$$

where $\mathrm{Y}_{\mathrm{ij}}$ is the individual observations of the $\mathrm{i}$-th treatment and the $\mathrm{j}$-th block, $\mu$ is the general effect, $t_{i}$ is the effect of the $\mathrm{i}$-th treatment, $\beta_{\mathrm{j}}$ is the effect of the $\mathrm{j}$-th block, $\varepsilon_{i j}$ is the random variation or experimental error.

\section{Results and Discussions}

Physical and chemical composition of maize grain, PW and the diets are shown in Table 1. The PW had higher $\mathrm{CP}, \mathrm{EE}$ and fibre (ADF and NDF) levels compared to maize, which corroborates with previous findings (Anonymous, 1990). Replacing maize with PW therefore increased the CP, EE and fibre contents of diets. The higher CP content of popcorn in comparison to popcorn grain has been reported by several authors (Graves \& West 1982; Park et al., 2000). The increase in EE of the diets could be attributed to the addition of oil during the production of popcorn (Borras et al., 2006).

Mean values of nutrient intake by lambs are given in Table 2. The mean DM and OM intakes were found to be similar $(\mathrm{P}>0.05)$ in the five groups, indicating that the replacement of maize grain either partially or completely with PW had no adverse effect on feed intake of growing lambs. This supports earlier observations (Dhakad et al., 2002) when the replacement of maize grain with wheat bran did not affect $(\mathrm{P}>0.05)$ dry matter intake (DMI) in growing lambs. However, contradictory observations (Kawas et al., 1991; Pathak et al., 1998) were reported on decreased DMI when grains were replaced with low energy diets on DMI of animals. Other workers (Fluharty et al., 1994) have reported enhanced feed intake on decreasing 
Table 1 Dietary ingredients and chemical composition of diets, popcorn waste and maize grain

\begin{tabular}{|c|c|c|c|c|c|c|c|}
\hline \multirow{2}{*}{ Ingredient $\%$} & \multicolumn{5}{|c|}{ Replacement level (\%) } & \multirow{2}{*}{$\begin{array}{l}\begin{array}{l}\text { Maize } \\
\text { grain }\end{array} \\
\end{array}$} & \multirow{2}{*}{$\begin{array}{l}\text { Popcorn } \\
\text { waste }\end{array}$} \\
\hline & 0 & 25 & 50 & 75 & 100 & & \\
\hline Maize & 56 & 42 & 28 & 14 & 0 & & \\
\hline Popcorn waste & 0 & 14 & 28 & 42 & 56 & & \\
\hline Wheaten bran & 10.6 & 8.7 & 8 & 8.9 & 8.8 & & \\
\hline Molasses meal & 10 & 10 & 10 & 10 & 10 & & \\
\hline Sunflower OC & 5 & 5 & 5 & 5 & 5 & & \\
\hline $\begin{array}{l}\text { Ammonium } \\
\text { sulphate }\end{array}$ & 0.6 & 0.5 & 0.3 & 0.3 & 0.3 & & \\
\hline Limestone & 1.1 & 1.1 & 1.1 & 1.1 & 1.2 & & \\
\hline Salt & 0.5 & 0.5 & 0.5 & 0.5 & 0.5 & & \\
\hline E. curvula (hay) & 6 & 8.0 & 8.9 & 8.0 & 8 & & \\
\hline Lucerne & 10 & 10 & 10 & 10 & 10 & & \\
\hline *Premix finisher & 0.2 & 0.2 & 0.2 & 0.2 & 0.2 & & \\
\hline $\mathrm{DM}$ & 90.9 & 89.0 & 89.6 & 89.6 & 87.8 & 89.3 & 88.9 \\
\hline $\mathrm{OM}$ & 93.3 & 92.1 & 93.1 & 92.5 & 92.6 & 98.7 & 96.2 \\
\hline $\mathrm{CP}$ & 15.5 & 16.7 & 16.9 & 17.2 & 17.7 & 10.1 & 12.9 \\
\hline $\mathrm{EE}$ & 3.8 & 4.3 & 4.5 & 4.9 & 5.4 & 4.6 & 11.0 \\
\hline $\mathrm{GE}(\mathrm{MJ} / \mathrm{kg} \mathrm{DM})$ & 16.5 & 16.6 & 16.1 & 15.9 & 16.2 & 16.8 & 16.6 \\
\hline $\mathrm{ADF}$ & 11.6 & 12.9 & 12.3 & 12.6 & 15.0 & 5.0 & 8.8 \\
\hline NDF & 29.0 & 30.8 & 31.2 & 31.8 & 35.1 & 29.9 & 32.1 \\
\hline
\end{tabular}

*Premix on DM basis: selenium $10 \mathrm{mg} / \mathrm{kg}$; potassium $215 \mathrm{mg} / \mathrm{kg}$; iron $50 \mathrm{mg} / \mathrm{kg}$; cobalt $20 \mathrm{mg} / \mathrm{kg}$; zinc $50 \mathrm{mg} / \mathrm{kg}$; manganese $1600 \mathrm{mg} / \mathrm{kg}$; copper $300 \mathrm{mg} / \mathrm{kg}$; iodine $70 \mathrm{mg} / \mathrm{kg}$; calcium $220 \mathrm{mg} / \mathrm{kg}$; phosphorus $280 \mathrm{mg} / \mathrm{kg}$; sulphur 30 $\mathrm{g} / \mathrm{kg}$; salt $950 \mathrm{~g} / \mathrm{kg}$.

DM - dry matter; OM - organic matter; CP - crude protein; EE - ether extract; GE - gross energy; ADF - acid detergent fibre; NDF - neutral detergent fibre.

levels of grains in a concentrate diet, but some workers (Singh et al., 1999) have shown that dietary replacement of grains had no effect on DMI of sheep. The present study further showed a higher $(\mathrm{P}<0.05)$ intake of $\mathrm{CP}$ and energy from the 25 and $50 \%$ replacement levels of maize grains compared to the other diets. The average daily gain $(\mathrm{ADG})$ was the highest $(\mathrm{P}<0.05)$ for the lambs fed diets containing 25 and $50 \%$ PW replacement levels (Table 2). This may be attributed to the higher intakes of CP and energy of lambs fed these two diets compared to the other diets, and indicates that the efficiency of gain is closely related to the intakes of CP and energy (Fashina-Bombata et al., 1994). Haddad et al. (2001) also reported higher gains in Awassi lambs that had a higher CP intake compared to those that had a lower CP intake. The growth rate was lower $(\mathrm{P}<0.05)$ at 75 and $100 \% \mathrm{PW}$ inclusion levels, indicating reduced growth of lambs fed on higher replacement levels of maize grains with PW as compared to the lambs fed diets containing less than $50 \% \mathrm{PW}$. This corroborates with the finding of Dhakad et al. (2002) who observed poor growth rates in lambs fed on diets containing $100 \%$ replacement of maize grain with wheat bran compared to diets containing lower replacement levels. Replacing maize with feed grade wheat at $75 \%$ level in a concentrate diet for lambs resulted in ADG of $154 \mathrm{~g} / \mathrm{d}$ (Tripathi et al., 2007), which was higher than $109 \mathrm{~g} / \mathrm{d}$ obtained with the diet that contained $75 \%$ of $\mathrm{PW}$ in the present study. 
Table 2 Effect of dietary substitution of maize with popcorn waste on feed intake (g/lamb/d), ADG (g/d) and FCR $(\mathrm{kg} / \mathrm{kg})$ in lambs $(\mathrm{n}=8)$

\begin{tabular}{|c|c|c|c|c|c|c|c|}
\hline & \multicolumn{5}{|c|}{ Substitution level (\%) } & \multirow{2}{*}{ s.e.m. } & \multirow{2}{*}{ P-value } \\
\hline & 0 & 25 & 50 & 75 & 100 & & \\
\hline \multicolumn{8}{|c|}{ Feed intake $\mathrm{g} / \mathrm{lamb} / \mathrm{d}$} \\
\hline DMI & 960 & 1183 & 1344 & 877 & 1050 & 108.9 & 0.059 \\
\hline OMI & 895 & 1089 & 1251 & 812 & 972 & 100.9 & 0.058 \\
\hline CPI & $148.7^{\mathrm{b}}$ & $209.9^{\mathrm{a}}$ & $226.7^{\mathrm{a}}$ & $150.9^{b}$ & $175.6^{\mathrm{b}}$ & 39.3 & 0.001 \\
\hline GEI MJ/d & $9.2^{\mathrm{b}}$ & $11.7^{\mathrm{a}}$ & $11.8^{\mathrm{a}}$ & $8.0^{\mathrm{c}}$ & $9.6^{\mathrm{b}}$ & 1.332 & 0.005 \\
\hline EEI & $36.3^{\mathrm{c}}$ & $37.4^{\mathrm{c}}$ & $46.8^{\mathrm{b}}$ & $58.2^{\mathrm{a}}$ & $60.3^{\mathrm{a}}$ & 4.87 & 0.004 \\
\hline NDFI & 278 & 364 & 420 & 308 & 334 & 35.3 & 0.098 \\
\hline \multicolumn{8}{|c|}{ Growth performance } \\
\hline IBW kg & 24.7 & 25.2 & 25.3 & 26.1 & 24.3 & 0.447 & 0.081 \\
\hline FBW kg & $35.2^{\mathrm{b}}$ & $36.3^{\mathrm{b}}$ & $38.9^{\mathrm{a}}$ & $32.0^{\mathrm{d}}$ & $32.3^{\mathrm{c}}$ & 1.430 & 0.002 \\
\hline $\mathrm{ADG} g / \mathrm{d}$ & $190^{\mathrm{b}}$ & $215^{\mathrm{a}}$ & $226^{\mathrm{a}}$ & $109^{\mathrm{d}}$ & $146^{\mathrm{c}}$ & 21.24 & 0.001 \\
\hline FCR kg/kg & $5.1^{\mathrm{e}}$ & $5.5^{\mathrm{d}}$ & $6.0^{\mathrm{c}}$ & $8.1^{\mathrm{a}}$ & $7.2^{\mathrm{b}}$ & 0.94 & 0.039 \\
\hline
\end{tabular}

Data on the apparent digestibility coefficients (\%) of different nutrients are given in Table 3. The digestibility of DM, OM, energy and fibre was found to be similar $(\mathrm{P}>0.05)$ among the five diets, indicating that replacement of maize grain with PW even at $100 \%$ level had no adverse effect on digestibility of these nutrients. This agrees with the results of Dhakad et al. (2002) and Garg et al. (2004) who have also reported no adverse effect on the digestibility of these nutrients when maize grains were replaced with wheat bran in the diets of growing lambs. However, the apparent digestibility of CP was higher $(\mathrm{P}<0.05)$ for diets with 25 and $75 \%$ replacement of maize with PW. The digestibility of the EE was higher $(\mathrm{P}<0.05)$ in the diets that contained 75 and $100 \%$ PW compared to the other diets. This may be due to higher EE intake of lambs in these treatments. This corroborated with the results of Luginbuhl et al. (2000) who reported an increased EE digestibility with increased $\mathrm{EE}$ intake in goats fed diets that contained 8 and $16 \%$ whole cottonseed compared to those that were fed on the control diet. Similarly, Nath \& Kehar (1969) reported a lower EE digestibility at lower EE intake. Furthermore, it can be expected that the digestibility of fibre (NDF) would be reduced with increased PW in diets which subsequently increased dietary EE. Different studies (Hall et al., 1990; Jenkins, 1993; Pavan et al., 2007) have reported a reduction in the digestibility of fibre with increased dietary EE. A possible explanation for the reduction in fibre digestibility with increased dietary EE is that fat inclusion depressed the attachment of ruminal microorganisms to the fibre, and thus decreased fibre digestion by creating a hydrophobic barrier on the fibrous feedstuff (Devendra \& Lewis, 1974). However, the digestibility of fibre in the present study was not $(\mathrm{P}>0.05)$ affected by an increased EE content in the PW treatments. This could be explained by the EE content of the diets which was less than 5\% (Moore et al., 1986). The intake and digestibility characteristics of the present study were of typical high-concentrate fed animals, in which the digestibility co-efficient of DM and CP was $68-78 \%$ and $72-81 \%$, respectively, which were comparable to those of Tripathi et al. (2007).

Data on the $\mathrm{N}$ intake and utilization of the diets by lambs are given in Table 4. The intake of $\mathrm{N}$ differs significantly $(\mathrm{P}<0.05)$ among treatments and therefore $\mathrm{N}$ retention was expressed as percentage of $\mathrm{N}$ intake. The highest $\mathrm{N}$ retention as a percentage of intake occurred when 25 to $50 \%$ of the maize grain in the diet was replaced by PW. The increase in $\mathrm{N}$ intake from these diets could be attributed to a better digestibility of $\mathrm{N}$ resulted in an increase in $\mathrm{N}$ absorption, showing a more efficient $\mathrm{N}$ use when 25 and $50 \%$ 
PW are included in lamb diets. A reduced $(\mathrm{P}<0.05) \mathrm{N}$ retention occurred in the diet that contained $100 \%$ $\mathrm{PW}$, which indicates that replacement of maize grain above $75 \%$ level with $\mathrm{PW}$ in the diet has an adverse effect on N metabolism in lambs. This is consistent with the finding by Garg et al. (2004) whereby a reduced $\mathrm{N}$ retention occurred in sheep fed on concentrate that contained more than $50 \%$ replacement level of maize grain with de-oiled rice bran. The highest $(\mathrm{P}<0.05) \mathrm{N}$ retention $(\mathrm{g} / \mathrm{d})$ was found in the diet with $50 \%$ replacement of maize with $\mathrm{PW}$ indicating a more efficient utilization of dietary $\mathrm{N}$.

Table 3 Effect of dietary substitution of maize with popcorn waste on nutrient digestibility coefficients (\%) and metabolizable energy (ME) of the diet by lambs $(n=8)$

\begin{tabular}{|c|c|c|c|c|c|c|c|}
\hline & \multicolumn{5}{|c|}{ Substitution level (\%) } & \multirow{2}{*}{ s.e.m. } & \multirow{2}{*}{ P-value } \\
\hline & 0 & 25 & 50 & 75 & 100 & & \\
\hline \multicolumn{8}{|c|}{ Apparent digestibility coefficients (\%) } \\
\hline Dry matter & 72.0 & 71.9 & 73.4 & 67.8 & 70.6 & 2.53 & 0.304 \\
\hline Organic matter & 72.4 & 72.0 & 73.6 & 66.9 & 71.1 & 2.56 & 0.322 \\
\hline Crude protein & $76.6^{\mathrm{b}}$ & $79.7^{\mathrm{a}}$ & $71.9^{c}$ & $80.6^{\mathrm{a}}$ & $75.8^{\mathrm{b}}$ & 0.938 & 0.001 \\
\hline Energy & 72.2 & 72.1 & 65.4 & 72.0 & 69.7 & 2.50 & 0.291 \\
\hline Ether extract & $86.5^{\mathrm{c}}$ & $89.4^{b}$ & $84.9^{\mathrm{d}}$ & $90.7^{\mathrm{a}}$ & $90.6^{\mathrm{a}}$ & 1.084 & 0.005 \\
\hline NDF & 47.6 & 50.3 & 45.8 & 56.8 & 48.1 & 4.21 & 0.418 \\
\hline $\mathrm{ME}(\mathrm{MJ} / \mathrm{kg} \mathrm{DM})$ & 9.9 & 10.2 & 9.1 & 9.6 & 9.4 & 0.83 & 0.072 \\
\hline
\end{tabular}

${ }^{\mathrm{a}-\mathrm{d}}$ Means in the same row with different superscripts differ significantly $(\mathrm{P}<0.05)$.

NDF - neutral detergent fibre.

Table 4 Effect of dietary substitution of maize with popcorn waste on nitrogen $(\mathrm{N})$ intake $(\mathrm{g} / \mathrm{kg} \mathrm{DM})$, excretion and retention in rams $(\mathrm{n}=8)$

\begin{tabular}{lcccccccc}
\hline & \multicolumn{9}{c}{ Substitution level (\%) } & s.e.m. & P-value \\
\cline { 2 - 5 } & 0 & 25 & 50 & 75 & 100 & & 0.001 \\
NI (g/d) & $59.1^{\mathrm{c}}$ & $71.5^{\mathrm{b}}$ & $87.9^{\mathrm{a}}$ & $52.2^{\mathrm{d}}$ & $36.5^{\mathrm{e}}$ & 6.28 & 0.010 \\
Faecal N (g/d) & $5.55^{\mathrm{c}}$ & $6.84^{\mathrm{b}}$ & $10.17^{\mathrm{a}}$ & $4.83^{\mathrm{c}}$ & $6.78^{\mathrm{b}}$ & 0.924 & 0.171 \\
N urine (g/d) & 3.98 & 2.96 & 2.27 & 1.93 & 2.54 & 0.582 & 0.015 \\
TN excretion (g/d) & $9.53^{\mathrm{b}}$ & $9.80^{\mathrm{b}}$ & $12.44^{\mathrm{a}}$ & $6.76^{\mathrm{c}}$ & $9.32^{\mathrm{b}}$ & 1.298 & 0.001 \\
N retention (g/d) & $49.6^{\mathrm{c}}$ & $61.7^{\mathrm{b}}$ & $75.4^{\mathrm{a}}$ & $45.4^{\mathrm{b}}$ & $27.2^{\mathrm{d}}$ & 5.12 & 0.001 \\
Retention (\%) & $84.13^{\mathrm{c}}$ & $86.47^{\mathrm{a}}$ & $85.85^{\mathrm{b}}$ & $87.23^{\mathrm{a}}$ & $74.58^{\mathrm{d}}$ & 0.876 & 0.001
\end{tabular}

${ }^{\mathrm{a}-\mathrm{e}}$ Means in the same row with different superscripts differ significantly $(\mathrm{P}<0.05)$.

NI - nitrogen intake; TN - total nitrogen.

\section{Conclusions}

It is concluded that low cost popcorn waste can replace up to $50 \%$ of maize grain in high concentrate diets to support lamb growth rate of $190-226$ g per day. 


\section{Acknowledgements}

The authors wish to thank the Gauteng Department of Agriculture, Conservation and Environment for financial support of this research.

\section{References}

Animal Ethics Committee, 2008. Animal Ethics Committee of the ARC-Animal Production Institute, Irene, South Africa.

Anonymous, 1990. Popcorn replaces yellow corn in starter, grow to finish diets. Swine Research Digest. National Hog Farmer, February 15. pp. 42-43.

AOAC, 1990. Official Methods of Analysis. $15^{\text {th }}$ ed. Association of Official Analytical Chemists, Washington, DC, USA.

AOAC, 1995. Official Methods of Analysis. $16^{\text {th }}$ ed. Association of Official Analytical Chemists, Washington, DC, USA.

ARC, 1984. The Nutrient Requirements of Ruminant Livestock. Suppl. No 1. Agricultural Research Council. Commonwealth Agricultural Bureaux, Slough, England.

Borras, F., Seetharaman, K., Yao, N, Robutti, J.L., Percibaldi, N.M. \& Eyherabide, G.H., 2006. Relationship between popcorn composition and expansion volume and discrimination of corn types by using zein properties. Cereal Chem. 83 (1), 86-92.

Devendra, C. \& Lewis, D., 1974. The interaction between dietary lipids and fibre in the sheep. 2. Digestibility studies. Anim. Prod. 19,67-76.

Dhakad, A., Garg, A.K., Singh, P. \& Agrawai, D.K., 2002. Effect of replacement of maize grain with wheat bran on the performance of growing lambs. Small Rumin. Res. 43, 227-234.

Fashina-Bombata, H.A., Fanimo, A.O. \& Weingartner, K., 1994. Effect of extruded fullfat soyabean meal as replacement for groundnut meal on performance, carcass characteristics and serum metabolites of weaner-grower pigs. Anim. Feed Sci. Technol. 47, 171-176.

Fluharty, F.L., Loerch, S.C. \& Smith, F.E., 1994. Effects of energy density and protein source on diet digestibility and performance of calves after arrival at the feedlot. J. Anim. Sci. 72, 1616-1622.

Garg, A.K., Singh, P., Malik, R. \& Agrawal, D.K., 2004. Effect of replacing maize grain with de-oiled rice bran on intake and utilization of nutrients in adult ewes. Small Rumin. Res. 52, 75-79.

Genstat For Windows ${ }^{\circledR} 2000$. Release 4.2. $5^{\text {th }}$ ed. VSN International Ltd., Oxford, UK.

Gokmen, S., 2004. Effects of moisture content and popping method on popping characteristics of popcorn. J. Food Eng. 65 (3), 357-362.

Graves, C.R. \& West, D.R., 1982. Grain protein variation in corn hybrids from 1980 through 1982 (Maize, forage composition). Tennese Farm Home Sci. 124, 8-9.

Haddad, S.G., Nasr, R.E. \& Muwalla, M.M., 2001. Optimum dietary protein level for finishing Awassi lambs. Small Rumin. Res. 39, 41-46.

Hall, K.L., Goetsch, A.L., Landis, K.M., Forster, J.L.A. \& Brake, A.C., 1990. Effects of a fat and ground maize supplement on feed intake and digestion by cattle consuming Bermudagrass (Cynodon dactylon). Anim. Feed Sci. Technol. 30, 275-288.

Jenkins, T.C., 1993. Lipid metabolism in the rumen. J. Dairy Sci. 76, 3851-3863.

Kawas, J.R., Lopes, J., Danelon, D.L. \& Lu, C.D., 1991. Influence of forage to concentrate ration on intake, digestibility, chewing and milk production of dairy goats. Small Rumin. Res. 4, 11-18.

Lehmann, M. \& Meeske, R., 2006. Substituting maize grain with barley grain in concentrates fed to Jersey cows grazing kikuyu-ryegrass pasture. S. Afr. J. Anim. Sci. 36, 175-180.

Luginbuhl, J.M., Poore, M.H. \& Conrad, A.P., 2000. Effect of level of whole cottonseed on intake, digestibility, and performance of growing male goats fed hay-based diets. J. Anim. Sci. 78, 1677-1683.

McDonald, P., Edwards, R.A., Greenhalgh, J.F.D. \& Morgan, C.A., 1995. Chapter 11: Evaluation of foods. In: Animal Nutrition. $5^{\text {th }}$ ed., Longman Scientific and Technical, Longman House, Burnt Mill, Harlow, England. pp. 238-265.

Moore, J.A., Swingle, R.S. \& Hale, W.H., 1986. Effects of whole cottonseed, cottonseed oil or animal fat on digestibility of wheat straw diets by steers. J. Anim. Sci. 63, 1267-1273.

Nath \& Kehar, 1969. Effect of fat supplementation in the digestion of nutrients in buffalo (Bos bubalis) bulls. Indian Vet. J. 46, 699-702. (cited by Singh et al., 1999). 
Park, D., Allen, K.G.D., Stermitz, F.R. \& Maga, J.A., 2000. Chemical composition and physical characteristics of unpopped popcorn hybrids. J. Food Comp. Anal. 13, 921-934.

Pathak, N.N., Sahoo, A., Singh, P., Chaudhary, L.C., Agarwal, N. \& Kamra, D.N., 1998. Voluntary feed intake and nutrient digestibility in lactating crossbred cows fed ad libitum green berseem with concentrate replaced by wheat bran. Indian J. Dairy Sci. 51, 157-161.

Pavan, E., Duckett, S.K. \& Andrae, J.G., 2007. Corn oil supplementation to steers grazing endophyte-free tall fescue. 1. Effects of in vivo digestibility, performance and carcass traits. J. Anim. Sci. 85, $1330-1339$.

Ristanovic, D., 2001. Cereal crops: Maize (Zea mays L.). Crop production in Tropical Africa Ed. Raemaekers, R.H. Ministry of Foreign Affairs, External Trade and International Co-operation, Brussels (Belgium). Directorate General for International Co-operation, Brussels, Belgium. pp. 23-45.

Schepers, A., 1989. Popcorn takes on new flavors, fat, and sodium. Environ. Nutr. 12, 4-5.

Singh, P., Garg, A.K., Malik, R. \& Agrawal, D.K., 1999. Effects of replacing barley grain with wheat bran on intake and utilization of nutrients in adult sheep. Small Rumin. Res. 31, 215-219.

Snedecor, G.W. \& Cochran, W.G., 1980. Statistical Methods. $7^{\text {th }}$ Edition, Iowa State University Press. Ames, Iowa, USA.

Strydom, P.E., 2008. Do indigenous Southern African cattle breeds have the right genetics for commercial production of quality meat? Meat Sci. 80, 86-93.

Tripathi, M.K., Karim, S.A., Chaturvedi, O.H. \& Verma, D., 2007. Nutritional value of animal feed grade wheat as replacement for maize in lamb feeding for mutton production. J. Sci. Food Agric. 87, 2447-2455.

Van Soest, P.J., Robertson, J.B. \& Lewis, B.A., 1991. Methods of dietary fiber, neutral detergent fiber, and non-starch polysaccharides in relation to animal nutrition. J. Dairy Sci. 74, 3583-3597.

Vicente, B., Valencia, D.G., Perez-Serrano, M., Lazaro, R. \& Mateos, G.G., 2008. The effects of feeding rice in substitution of corn and the degree of starch gelatinization of rice on the digestibility of dietary components and productive performance of young pigs. J. Anim. Sci. 86, 119-126.

Wedegaertner, T.C. \& Johnson, D.E., 1983. Monensin effects on digestibility, methanogenesis and heat increment of a cracked corn-silage diet fed to steers. J. Anim. Sci. 57, 168-177. 